Int. J. Dev. Biol. 61: 785-792 (2017)

doi: $10.1387 / \mathrm{ijdb} .170210 \mathrm{yw}$

\title{
Characterization of an amphioxus heat-shock protein gene promoter and its application in vivo
}

\author{
CHAOFAN XING\#, GUANG LI", XIAN LIU, XI DENG and YIQUAN WANG* \\ State Key Laboratory of Cellular Stress Biology, School of Life Sciences, Xiamen University, Xiangan District, \\ Xiamen, Fujian, China
}

\begin{abstract}
Amphioxus is a good proxy for studying the evolution and development of mechanisms during the invertebrate to vertebrate transition. However, one of the major limitations of amphioxus as a model organism is the lack of well-developed technical approaches. Promoters of genes encoding heat shock proteins are useful tools for gene function studies. In the present study, we tested heat shock temperatures on 4-cell, 128-cell, late blastula, mid-gastrula and late gastrula amphioxus embryos and optimized the heat shock conditions. We then examined the expression profile of the endogenous $\mathrm{Hsp} 70$ gene in embryos heat-shocked under optimum conditions. RT-qPCR revealed that the expression of $\mathbf{H s p 7 0}$ could be induced in embryos by heat shock after the 128-cell stage, and in situ hybridization showed that the induced $H s p 70$ expression was predominantly detected in epidermal ectoderm. Further, we constructed two reporter gene expression plasmids carrying the Hsp70 promoter to evaluate its efficiency in vivo. Microinjection experiments showed strong red fluorescence or LacZ staining signals in injected embryos after heat shock treatment. In contrast to endogenous Hsp70, reporter gene expression was found in all three germ layers at equivalent levels. Finally, using the $\mathrm{Hsp} 70$ promoter, we conducted a preliminary functional analysis of two amphioxus genes, $\mathrm{Vg} 1$ and $\mathrm{Cer}$, which play essential roles in left-right patterning in vertebrates. After heat shock at late blastula, mid-gastrula or early neurula stages, ectopic expression of $\mathbf{V g} 1$ was detected in each group of treated embryos. Phenotype observation at 3-gill-slit larvae stage showed that ectopic $\mathbf{V g} 1$ expression led to two-left-side or left-right reversal phenotypes, and that of Cer caused a two-right-side phenotype. Our study establishes a thermo-inducible gene expression system which will be a useful tool for gene function investigation in amphioxus embryos.
\end{abstract}

KEY WORDS: amphioxus, Hsp70 promoter, inducible gene expression, embryo development, heat shock

\section{Introduction}

Amphioxus, being a sister group of urochordates and vertebrates, represents the most basally-diverged lineage of chordates (Bourlat et al., 2006, Delsuc et al., 2006). Like vertebrates, amphioxus possesses a dorsal hollow neural tube, a notochord, a perforated pharynx with gill slits and segmented axial muscles (Koop and Holland, 2008). Moreover, the amphioxus genome has not undergone the two-rounds of genome duplications that occurred during the early evolution of vertebrates, and has maintained most features of the ancestral chordate (Putnam et al., 2008). Because of this morphological and genetic simplicity, amphioxus has been regarded as a valuable model for studies in genetics, developmental biology and evolutionary biology (Bertrand and Escriva, 2011, Holland et al., 2004, Koop and Holland, 2008). Techniques such as in situ hybridization and immunohistochemical staining have been applied in amphioxus for many years, followed by whole genome sequencing of two amphioxus species (Huang et al., 2014, Putnam et al., 2008), and methods for acquirement of the second filial generation of amphioxus (Wang et al., 2006, Zhang et al., 2007), year-round spawning (Benito-Gutierrez et al., 2013, Li et al., 2012) as well as induced breeding (Li et al., 2015) and genome editing in B. belcheri and B. floridae (Li et al., 2014, Wang et al., 2015). All those achievements made amphioxus more applicable as a laboratory model organism. However, molecular tools for amphioxus, particularly effectively working in amphioxus, are obviously lacking

Abbreviations used in this paper: HSP, heat shock protein.

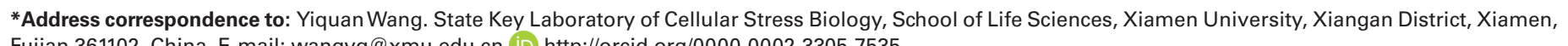
Fujian 361102, China. E-mail: wangyq@xmu.edu.cn (iD) http://orcid.org/0000-0002-3305-7535

\#These authors contributed equally to this work. 
and their development is required for subsequent experimental studies using this new model animal (Bertrand and Escriva, 2011, Garcia-Fernandez and Benito-Gutierrez, 2009).

Activation of target genes of interest in a temporal and spatial manner is frequently required in embryonic development studies, and can be achieved using heat-shock inducible promoters. Those promoters have been used in most well-developed model animals, such as Drosophila (Pelham and Bienz, 1982), zebrafish (Halloran et al., 2000), mouse (Hunt and Calderwood, 1990), medaka (Oda et al., 2010) and Xenopus (Sauert et al., 2012). Nevertheless, in our preliminary experiments, current commercial heat-shock promoters are not efficacious enough for amphioxus studies. For this reason, Li and colleagues have cloned a heat-shock promoter from amphioxus $B$. belcheriand evaluated its activity in Epithelioma Papulosum Cyprini (EPC) cell line and zebrafish embryos, but not in amphioxus embryos due to technical limitations in unfertilized egg acquirement and microinjection for amphioxus at that time ( $\mathrm{Li}$ et al., 2012). Thus, the activity and characters of this promoter remain to be verified in amphioxus embryos. Besides, the heat-inducible features of amphioxus endogenous Hsp70gene in amphioxus also need to be characterized, which is valuable for the application of this promoter in ectopic gene expression studies. In the present study, we tested different shock conditions on five developmental stages of $B$. floridae embryos and identified the optimum ones for each stage according to malformed embryo ratios. Further, we examined the expression profile of endogenous $\mathrm{Hsp} 70$ gene after heat shock at different embryonic development stages under a certain heat shock condition, and evaluated the activity of the promoter in amphioxus embryos. The result showed that both endogenous Hsp70 gene and exogenous genes under the control of Hsp70 promoter could be induced to express throughout the embryo after heat shock. Additionally, using the promoter we conducted a preliminary functional analysis on amphioxus Cer and $\mathrm{Vg} 1$ genes and demonstrated that ectopic activation of either of the two genes caused left-right patterning defects in amphioxus embryos.

\section{Results}

\section{Optimization of heat-shock conditions for developing amphioxus embryos}

To determine the optimum heat shock condition, we heatshocked amphioxus embryos (which were originally reared at $25^{\circ} \mathrm{C}$ ) at $31^{\circ} \mathrm{C}$ or $35^{\circ} \mathrm{C}$ for a period of time. The effect of heat shock was evaluated by counting the deformity ratio of the embryos at early larval stage. As shown in Fig. 1, the deformity ratios of those embryos heat-shocked at $31^{\circ} \mathrm{C}$ are low and approximate to that of negative control, no matter at what embryonic stages or for how long of heat shock duration. However, most embryos died soon and the reminder deformed seriously if 4-cell or 128-cell stage embryos were heat-shocked at $35^{\circ} \mathrm{C}$. By contrast, the deformity ratios significantly decreased to $10 \%$ to $25 \%$ when the treatment $\left(35^{\circ} \mathrm{C}\right)$ was performed on the embryos at LB, MG or LG stages. The result indicates that the early embryos are more sensitive to high temperature than LB or later embryos. Thus for the overall consideration of heat shock effect and embryonic deformity, we adopted respectively $31^{\circ} \mathrm{C}-30 \mathrm{~min}$ and $35^{\circ} \mathrm{C}-30 \mathrm{~min}$ combinations as optimum heat shock conditions respectively for early cleavage stage embryos (4-cell and 128-cell stages) and late stage embryos (LB, MG, LG or subsequent stages).

\section{Endogenous Hsp70 expression profile after heat shock}

The expression of $\mathrm{Hsp} 70$ gene can be efficiently induced by heat shock in adult amphioxus (Li et al., 2012) and in many other species (Oda et al., 2010, Stringham and Candido, 1993, Wysocka and Krawczyk, 2000). To evaluate the response of amphioxus embryos to heat shock under the above optimized conditions, we analyzed endogenous Hsp70 expression profiles using RT-qPCR. The results showed that almost no expression of the endogenous Hsp70 was detectable in all examined embryonic stages without heat shock in the negative control. By contrast, gene expression was strongly up-regulated in embryos after heat shock at LB, MG and 3-somite stages. In all experiments, induced expression reached the highest peak within one hour after heat shock, and then gradually decreased to a normal level in the subsequent five hours (Fig. 2A). The results also indicated no significant up-regulation of $\mathrm{Hsp} 70$ expression was detected in the embryos heat-shocked at 4-cell stage (Fig. 2A).

We further determined the spatial distribution of Hsp70 mRNA in normal and heat-shocked embryos using whole-mount in situ hybridization plus histological sections. The results revealed no Hsp70 expression in the un-heat-shocked control embryos (Fig.2 $\left.A^{\prime}, D^{\prime}, G^{\prime}\right)$ but strong expression in the embryos heat-shocked at $35^{\circ} \mathrm{C}$ (Fig.2 B', E', H'). The induced expression level was much higher in epithelial ectoderm than in neural ectoderm, mesoderm and endoderm (Fig.2 C', F', I').

\section{No endogenous Hsp70 expression in early embryos}

The gene expression profile indicated that endogenous $\mathrm{Hsp} 70$ expression could not be induced by heat shock at $31^{\circ} \mathrm{C}$ in the 4-cell stage embryos (Fig 2A). To determine when the gene began to respond to the heat simulation, we set the heat shock condition to $33^{\circ} \mathrm{C}$ for $30 \mathrm{~min}$ and used it to treat early stage embryos (4-cell, 16-cell, 32-cell, 64-cell, 128-cell, 256-cell and LB embryos). One hour after heat shock, we collected embryos and extracted total

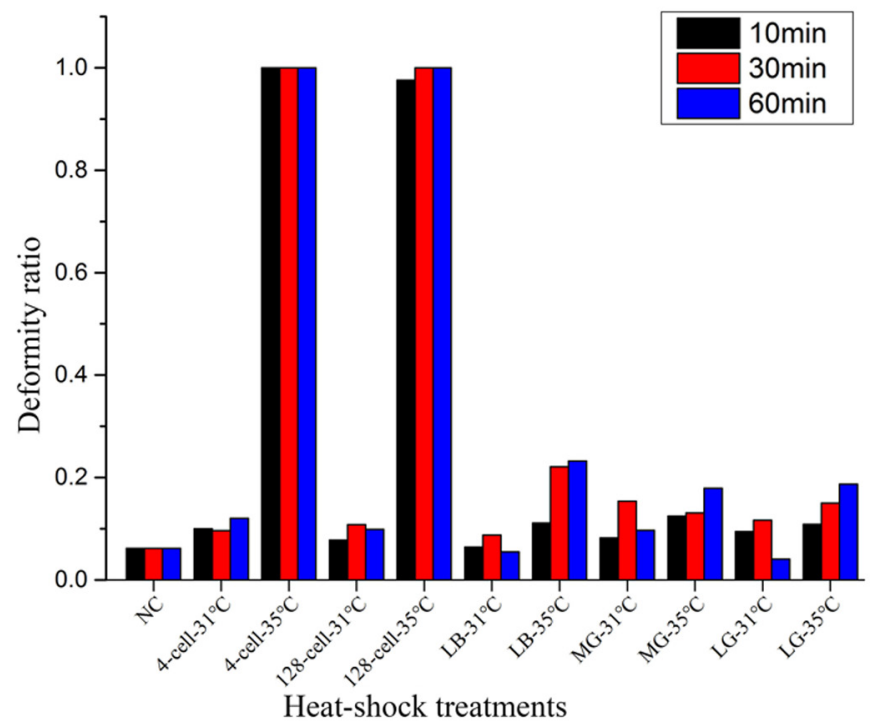

Fig. 1. Embryo deformity ratio at the larval stage after heat shock. The color columns show the deformity ratio with different heat-shock durations, as indicated in the corner. NC is a negative control without heat shock treatment, 4-cell, 128-cell, LB, MG and LG indicate different embryonic stages, and $31^{\circ} \mathrm{C}$ or $35^{\circ} \mathrm{C}$ denotes the heat shock temperature. 


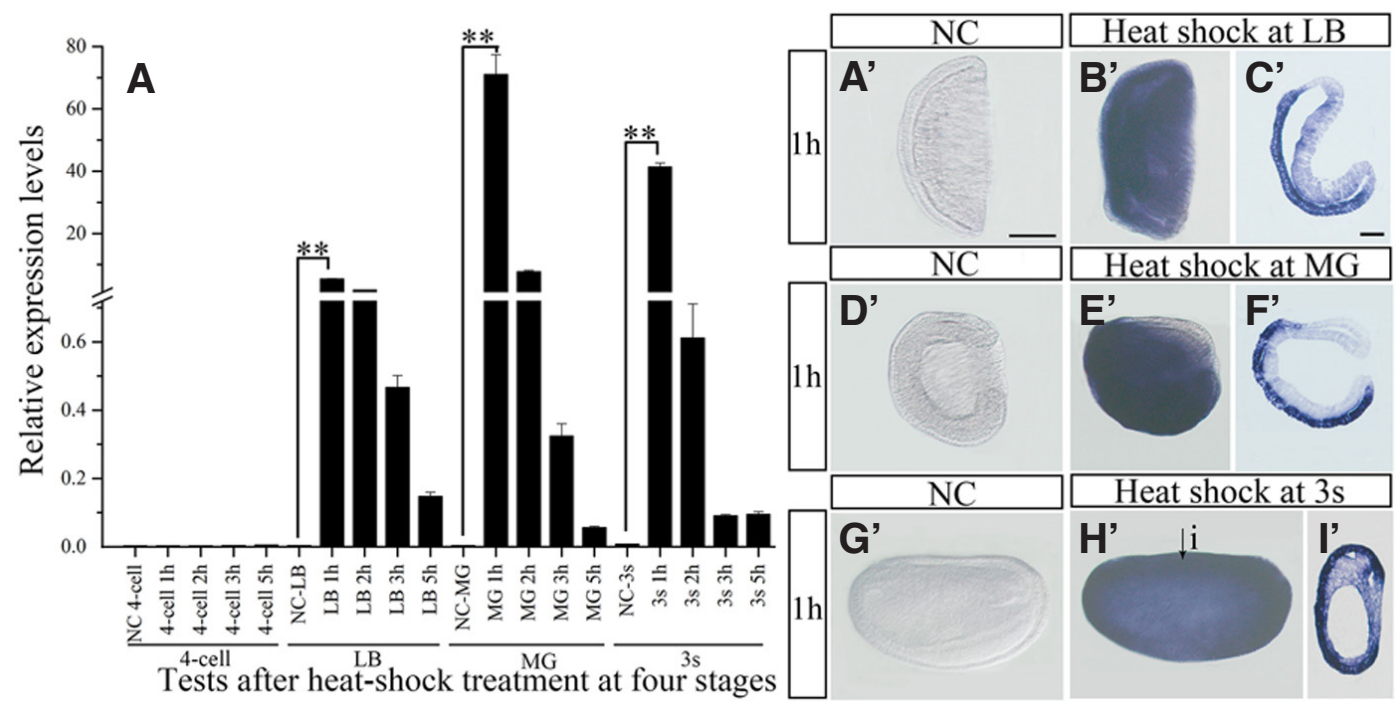

Fig. 2. Temporal and spatial expression pattern of endogenous Hsp70 in heat-shocked embryos. (A) RT-qPCR analysis of $\mathrm{Hsp70}$ gene expression in the embryos during the five hours 11 $h, 2 h, 3 h, 5 h)$ after heat shock at four developmental stages. ** indicates $\mathrm{P}<0.01$ compared with the negative control (NC). (B', E', $\left.\mathbf{H}^{\prime}\right)$ Distribution of Hsp70 mRNA in the embryos one hour after heat shock at $L B, M G$, and 3-somite (3s) stages. (A', D', G') Negative controls without heat shock. (C', $\left.\mathbf{F}^{\prime}\right)$ Coronal sections of the embryo in image $C$ and $F\left(\mathbf{I}^{\prime}\right)$ Cross section

through level $i$ in image $H^{\prime}$. All panels are from the left lateral view. Scale bars in $A^{\prime}, B^{\prime}, D^{\prime}, E^{\prime}, G^{\prime}, H^{\prime}$ are $50 \mu m$, and that in $C^{\prime}, F^{\prime}, I^{\prime}$ are $20 \mu m$.

RNA for RT-qPCR analysis. The result showed that the Hsp70 expression significantly increased in those embryos heat-shocked at 128 -cell or 256-cell stages although the increments at these two stages were much lower than that in the embryos treated at LB stage (Fig. 3). However, compared with the control, no gene expression change appeared in the embryos heat-shocked at 4-cell, 16-cell, 32-cell or 64-cell stages (Fig. 3). Thus, amphioxus embryos began to respond to the thermal stimulation from the 128-cell stage.

Use of the Hsp70 promoter for exogenous gene expression in B. floridae embryos

The $B$. belcheri Hsp70 promoter is inducible by heat stimuli in zebrafish embryos or carp EPC cell line (Li et al., 2012). The core

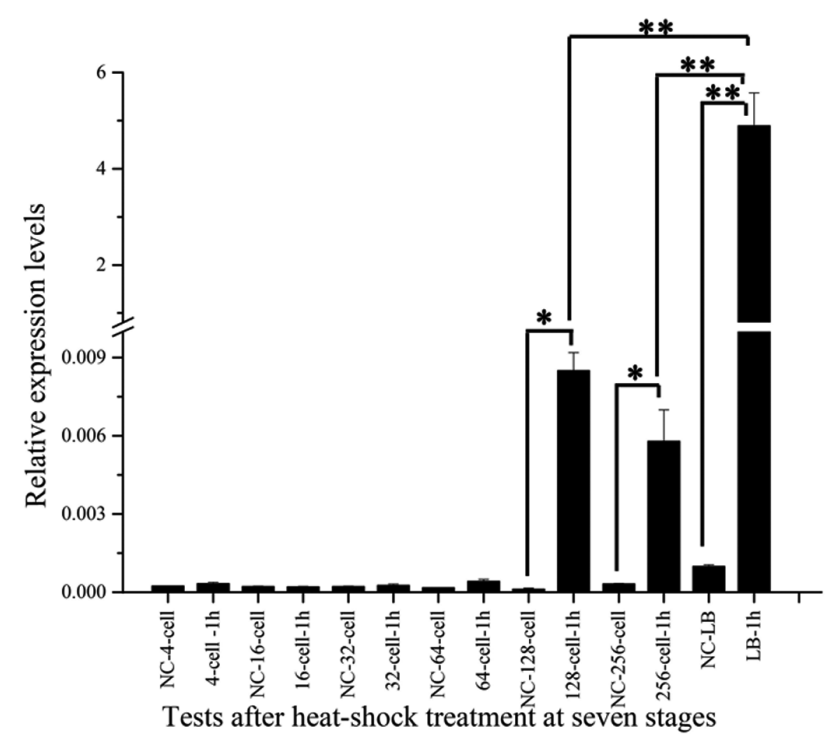

Fig. 3. RT-qPCR analysis of endogenous $H s p 70$ expression in embryos after heat shock at seven stages. NC, negative control. "* " represents the $P$ value is less than 0.05 . "**" indicates the $P$ value is less than 0.01 . elements of the Hsp70 promoter in the corresponding region are also highly conserved between $B$. belcheriand $B$. floridae. We thus presumed that the $B$. belcheri Hsp70 promoter should also work in $B$. floridae embryos. To detect the activity of the Hsp70 promoter in amphioxus embryos, we integrated the $B$. belcheri Hsp70 promoter upstream of the reporter genes $m C h e r r y$ or $L a c Z$, and microinjected the constructs into $B$. floridae unfertilized eggs and then dropped a few sperm for fertilization. Based on the observation in our pilot experiments, we heat-shocked all embryos at required stages under $33^{\circ} \mathrm{C}$ for $30 \mathrm{~min}$, and then collected samples for detection of reporter gene expression. In the embryos microinjected with the construct Hsp70::mCherry, red fluorescent signal initially appeared in several embryos $1.5 \mathrm{~h}$ after heat shock at the LB stage. By $2 \mathrm{~h}$ after the treatment, $87 \%(87 / 100)$ of embryos emitted strong red fluorescence in a dotted manner throughout the body (Fig. $4 \mathrm{~J}$ ). Similarly, $85.7 \%$ (78/91) of embryos heat-shocked at the 3-somite stage emitted bright red fluorescence 2 hours after the treatment (Fig. $4 \mathrm{~V}$ ). The red fluorescence was slightly increased 3 hours after heat shock (Fig. $4 \mathrm{~K}, \mathrm{~W}$ ) and still very bright till the early larva stage (Fig. $4 \mathrm{~L}, \mathrm{X}$ ). In addition, we also observed a very weak red fluorescence signal in few embryos injected Hsp70::mCherry construct without heat shock (data not shown), indicating a leakiness of the promoter.

We also injected embryos with the construct Hsp70::LacZ, heat-shocked them at LB, MG, or 3-somite stages, and examined them for $L a c Z$ gene expression. Similar to mCherry expression shown above, mosaic or regional LacZstaining signal was initially detected 2 hours after heat shock (Fig. 4 I', Q', K', S', N', V'), and sustained till 12 hours later (Fig.4 M', U', P', X').

\section{Application of the Hsp70 promoter for gene function examination in $\mathrm{B}$. floridae embryos}

Encouraged by the high activity of the Hsp70 promoter in vivo, we used it to examine gene function during amphioxus embryo development, and selected Vg1 and Cer for this primary analysis. Cerwas recently shown to be required for the formation of left-right asymmetry in amphioxus (Li et al., 2017). Similar to Cer, Vg1 is also expressed asymmetrically during amphioxus embryonic de- 
velopment (Onai et al., 2010, Soukup et al., 2015), but whether it is involved in amphioxus left-right determination remains unknown. We injected Hsp70::Vg1 or Hsp70::Cer plasmids into unfertilized eggs and heat-shocked them after fertilization at LB, MG and 3-somite stages respectively. In situ hybridization results showed that the induced expression of $V g 1$ appeared in all those three treatments within the subsequent five hours (Fig. 5). Further, we evaluated the effects of the expression of these two exogenous genes via morphological observation of the developing larvae. In most control larvae (injected but not heat-shocked), the mouth formed on the left side (Fig. 6 A). However, among the heat-shocked larvae injected with Hsp70::Vg1, around $21.7 \%$ to $45.8 \%$ of them developed a mouth on both sides, or on reverse (right) side (Fig. 6 B-D), whereas among the heat-shocked larvae injected with Hsp70::Cer, about $52.9 \%$ to $64.3 \%$ showed no mouth forming on either side (Fig.6 $\mathrm{F}-\mathrm{H})$. Similar phenotypes were also found in few injected but not heat-shocked control larvae (1/44 in the Hsp70::Vg1-injected control larvae and $3 / 20$ in the Hsp70::Cer-injected control larvae), which might be caused by the leakiness of the promoter as evidenced by ectopic expression of $V g 1$ in a few cells of the injected embryos.
The results indicate that $\mathrm{Vg} 1$ and Cer genes were important for the left-side identity development in amphioxus embryos. These results demonstrate that the $\mathrm{Hsp} 70$ promoter is a useful molecular tool for gene function studies in amphioxus.

\section{Discussion}

Given its key phylogenetic position and morphological characteristics, amphioxus has been used as a model for studying the development and evolution of vertebrates for many years (Acemel et al., 2016, Koop and Holland, 2008). In the past few years, several important steps have been made in amphioxus research, including genome sequencing of two amphioxus species (Huang et al., 2014, Putnam et al., 2008), establishing methods for inducing amphioxus spawning all year around (Li et al., 2012, Li et al., 2013, Li et al., 2015,) and generating amphioxus mutant at desired gene loci (Li et al., 2014, Wang et al., 2015). Nevertheless, many molecular tools like tissue-specific promoters and inducible gene expression systems are still lacking. We here report an efficient heat-shock inducible gene expression system using the amphioxus

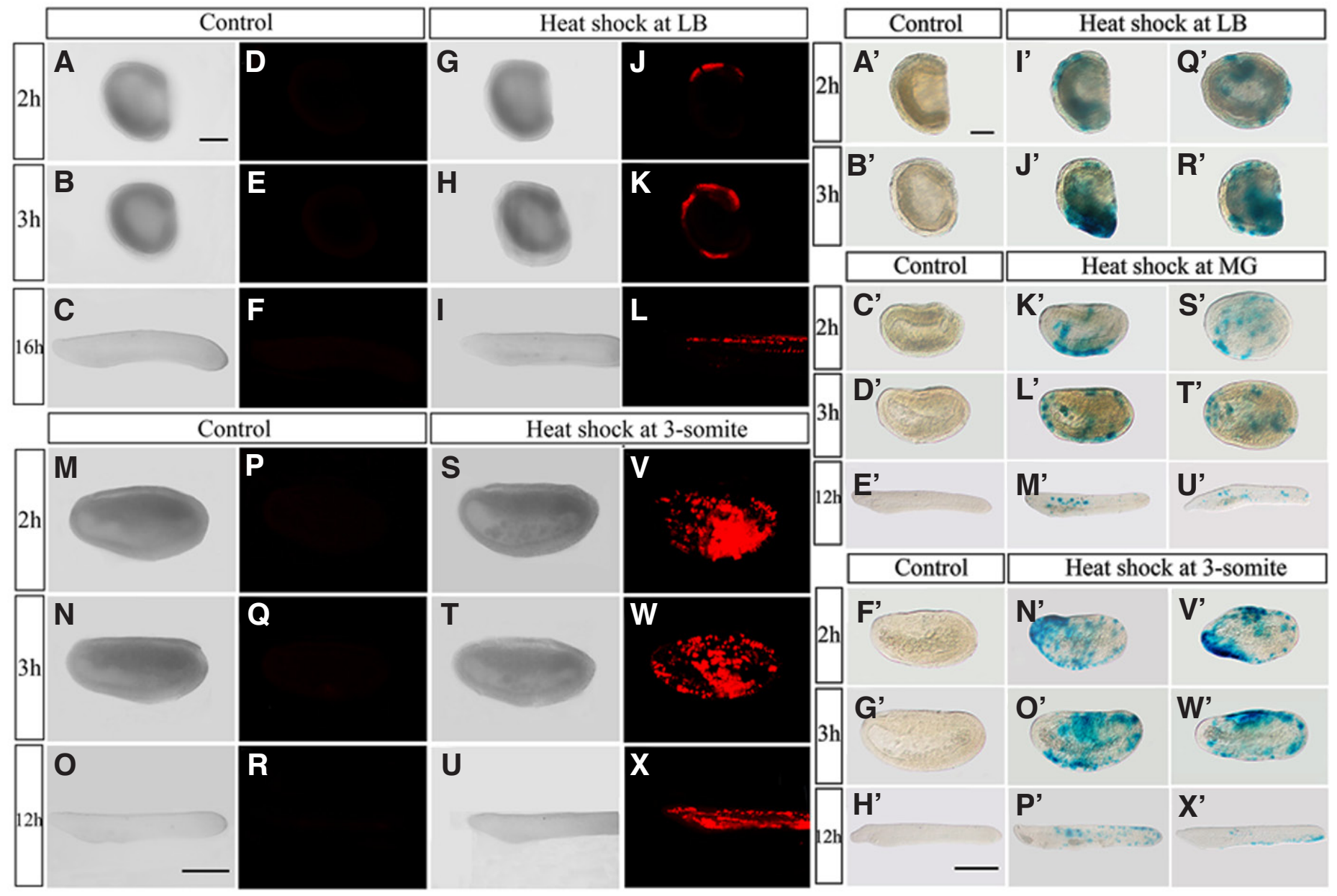

Fig. 4. Reporter gene expression in embryos injected with construct Hsp70::mCherry or Hsp70::LacZ. (A-F, M-R) show the control embryos injected Hsp70::mCherry without heat shock. Red fluorescence brightly emits 2 h (J, V), 3 h (K, W), 12 h (X) or 16 h (L) after the heat shock respectively at LB stage or 3-somite stage. (G-I, S-U) are corresponding bright field images of $(\mathrm{J}-\mathrm{L}, \mathrm{V}-\mathrm{X})$. $\left(\mathbf{A}^{\prime}-\mathbf{H}^{\prime}\right)$ show the control embryos injected Hsp70::LacZ without

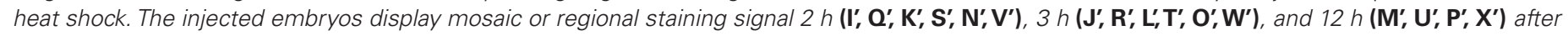
heat shock respectively at LB, MG, 3-somite stages. Scale bars are $100 \mu \mathrm{m}$ in images $12 \mathrm{~h}$ or $16 \mathrm{~h}$ after heat shock and 50 um in others. 
Hsp70 promoter. We evaluated the system to control exogenous Cer and $V g 1$ expression during amphioxus embryo development, and found that ectopic activation of either Cer or Vg1 could disrupt normal LR asymmetric development. This observation is consistent

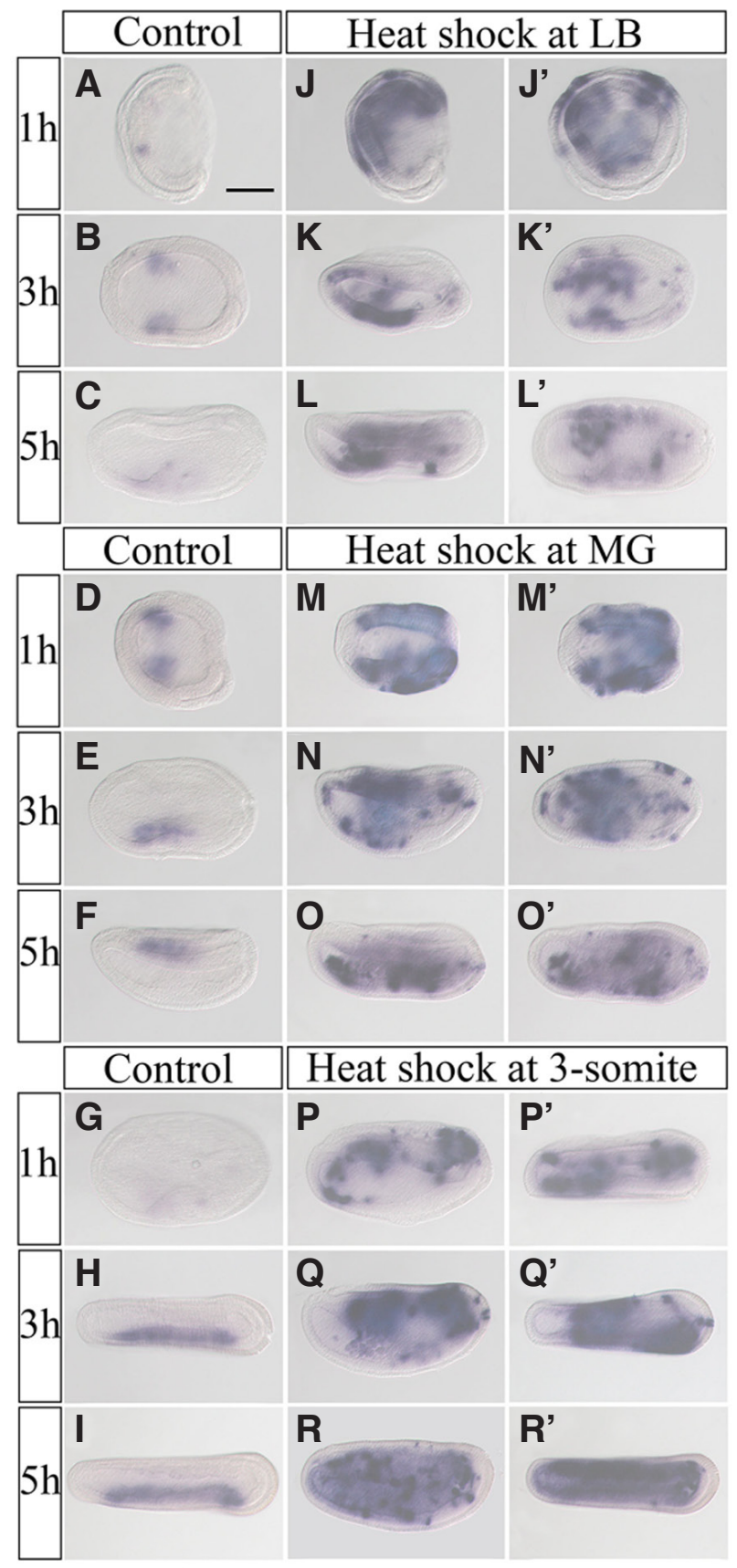

with our recent finding that $\mathrm{Cer}$ is required for correct right-side development in amphioxus embryogenesis (Li et al., 2017).

The embryonic expression pattern of $\mathrm{Hsp} 70$ gene has been widely studied in many different animals. Comparison of these data with the result presented in this study reveals several conserved expression features of $\mathrm{Hsp} 70$ between amphioxus and other animals. Firstly, as it in fish or Xenopus (Michiue and Asashima, 2005, Oda et al., 2010, Santacruz et al., 1997), Hsp70 in amphioxus is barely expressed during normal development but can be significantly induced by an approximately $10^{\circ} \mathrm{C}$ temperature increment. Secondly, like in vertebrates (Bienz, 1984a, Lele et al., 1997, Lang et al., 2000), induced Hsp70 expression in amphioxus also reaches its maximum level within one hour after heat shock, and then gradually decreases in subsequent development. Thirdly, in both amphioxus and Xenopus (Bienz, 1984a, Heikkila et al., 1985), as well as in sea urchin (Giudice, 1989) and Drosophila (Wang and Lindquist, 1998), Hsp70 expression cannot be activated by heat shock at very early developmental stages. In Xenopus, the earliest stage when Hsp70 can be induced by heat shock corresponds to the stage when zygotic gene expression is activated (Lang et al., 2000). This is probably the same case in amphioxus, since heat-shock-induced Hsp70 mRNA was detected only from the 128-cell stage on, when the zygotic genome is thought to be activated (Yang et al., 2016). Lastly, as it is in zebrafish (Lele et al., 1997) and Xenopus embryos (Lang et al., 2000), the induced Hsp70 expression level by heat shock in amphioxus embryos is not identical among different tissues.

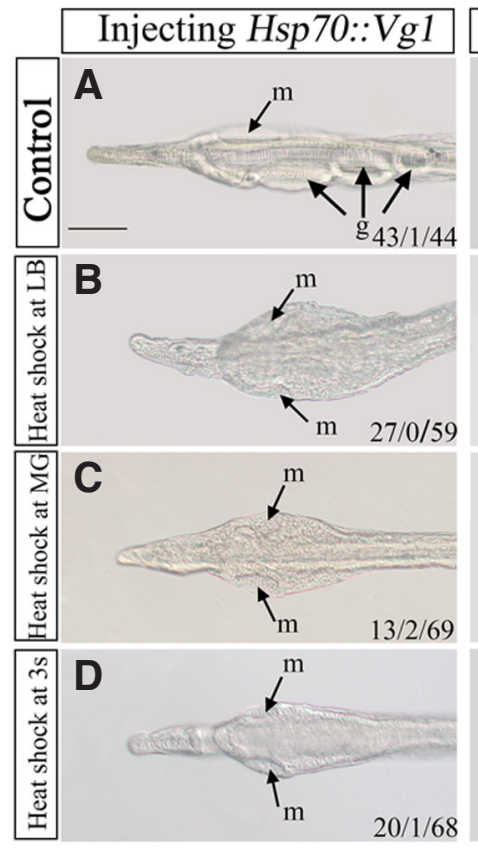

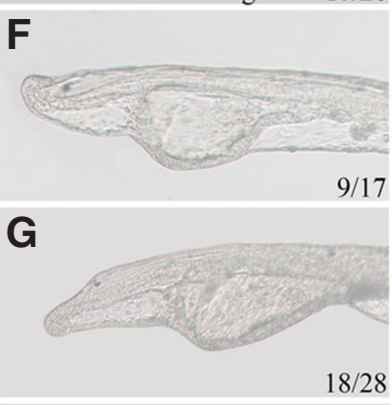

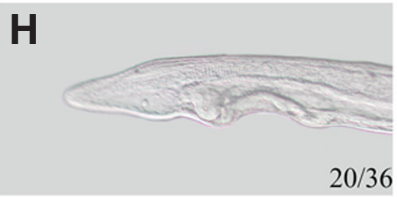

Fig. 5 (left). Exogenous gene expression in embryos injected with Hsp70::Vg1 plasmids after heat shock. (A-I) show the control embryos injected with Hsp70::Vg1 plasmids but not heat-shocked, showing a normal expression pattern of $\mathrm{Vg} 1$ gene in developing amphioxus embryos. (J-R) and (J'$\left.\mathbf{R}^{\prime}\right)$ are lateral and dorsal view images, showing exogenous Vg1 expression in the embryos injected with Hsp70::Vg1 and heat-shocked at LB, MG and 3-somite stages. "1h", "3h" and "5h" indicate samples collected at different times after heat shock. Scale bar in (A) is $50 \mu \mathrm{m}$ and applicable all images.

Fig. 6 (right). Mophological observation on 3-gill slit larvae injected with Hsp70::Vg1 or Hsp70::Cer plasmids and heat-shocked at LB, MG or 3-somite stages. (A, E) are control larvae injected but not heat-shocked. (B-D) are ventral views of the larvae injected with $\mathrm{Hsp} 70:: \mathrm{Vg} 1$ and heat-shocked at different developing stage, showing two-mouth phenotypes with a on both sides. (F-H) are lateral views of the larvae injected with Hsp70::Cer and heat-shocked, showing no mouth on either side. The first numbers indicate individuals as shown in this image, the middle ones represent deformed individuals with mouth on the right, and the last ones denote observed total larvae. $\mathrm{m}$, mouth; g, gill slit; Scale bar is 50 um and applicable to all images. 
The highly inducible activity of the endogenous Hsp70 gene by heat shock has made its promoter a useful tool for temporal manipulation of exogenous gene expression in many different species (Michiue and Asashima, 2005, Oda et al., 2010, Santacruz et al., 1997). To develop such a tool for amphioxus studies, we previously isolated a Hsp70 promoter from B. belcheri and showed its heat-inducible activity in zebrafish embryos and carp EPC cell line (Li et al., 2012). In the present study, we further demonstrated that this promoter could be used to activate exogenous gene expression very efficiently in $B$. floridae embryos. Moreover, compared with endogenous Hsp70 expression, exogenous gene expression driven by the promoter showed no obvious propensities among different tissues in the $B$. floridae embryos. This difference might be caused by cross-species utility of the B. belcheri Hsp70 promoter in the $B$. floridae embryos. It is also possible that the promoter used does not include the regulative sequence responsible for tissue-specific expression. A similar ubiquitous induction of exogenous gene expression by the Hsp70 promoter is also observed in Xenopus and fishes (Bajoghli et al., 2004, Michiue and Asashima, 2005, Oda et al., 2010), although their endogenous Hsp70 genes are not uniformly expressed in different tissues (Lele et al., 1997, Lang et al., 2000).

Taking all properties discussed above into consideration, we suggest three matters should be noted for a better application in amphioxus embryos. First, since the embryos are more susceptible to heat shock at early stage than those at late stage, a moderate heat shock condition should be taken for embryos between 128cell and late blastula stages. Among the four tested heat shock conditions $\left(31^{\circ} \mathrm{C}\right.$ for $30 \mathrm{~min}, 31^{\circ} \mathrm{C}$ for $60 \mathrm{~min}, 33^{\circ} \mathrm{C}$ for $30 \mathrm{~min}$ and $35^{\circ} \mathrm{C}$ for $15 \mathrm{~min}$ ), we found that $33^{\circ} \mathrm{C}$ for $30 \mathrm{~min}$ seems to be the best since it caused only mild levels of embryonic deformation, but still induced robust $m C h e r r y$ expression. As for embryos after the gastrula stage, $35^{\circ} \mathrm{C}$ for $30 \mathrm{~min}$ is recommended as most embryos are resistant to this shock condition and express the exogenous gene efficiently. Secondly, as observed in other animals, the Hsp70 promoter in amphioxus embryos also led to a very low level of leakiness of exogenous gene expression even without heat shock. Such leakiness will not be a problem if a high expression level of a gene is required to produce phenotypes since low leaking expression can not produce evident side-effects. However, if a gene functions at a very low expression level, the side-effects by leakiness should be considered during the experiment. Researchers could set delicate controls, such as $\mathrm{Hsp} 70$ construct-injected but non-shocked and/or un-injected but shocked controls, to exclude potential side-effects from the leakiness. Thirdly, the promoter is not suitable for genes that function in the early embryos before the 128-cell stage, because it cannot be activated by heat shock at such early stages. Fortunately, such inability would not matter in this promoter application for functional studies of many amphioxus genes because most developmentally essential genes execute their roles after the 128-cell stage. Moreover, overexpression of a certain gene at the early cleavage stages can be achieved by direct mRNA injection into unfertilized eggs.

\section{Materials and Methods}

\section{Animals}

Amphioxus Branchiostoma floridae was originally introduced from Dr. Jr-Kai Yu's lab and now is bred in our aquarium room. Animal cultivation and spawning induction were performed according to the previous reports (Li et al., 2013, Li et al., 2012, Zhang et al., 2007). Fertilization and embryo rearing were performed essentially according to previous description (Liu et al., 2013) with culture temperature adjusted to $25^{\circ} \mathrm{C}$ before or after heat shock.

\section{Heat shock experiments}

Generally, we transferred embryos at the required developmental stage into a beaker containing $100 \mathrm{ml}$ preheated seawater for heat shock. After that, we put the beaker together with those embryos into a $25^{\circ} \mathrm{C}$ incubator and cultured them till morphological observation. To find an optimum condition, we set seawater temperature at $31^{\circ} \mathrm{C}$ or $35^{\circ} \mathrm{C}$ and heat-shock duration for $10 \mathrm{~min}, 30 \mathrm{~min}$ or $60 \mathrm{~min}$ respectively. We treated about 100 embryos for each temperature-duration combination, and also included a similar number of non-shocked embryos from the same clutch as a negative control. When the embryos developed into early larval stage, we evaluated the ratio of malformed larva number to the total number of treated larvae according to the morphological count of each treatment.

\section{Real-time quantitative PCR (RT-qPCR)}

To quantify the dynamic of the endogenous $\mathrm{Hsp} 70$ gene, we respectively treated embryos at the 4 -cell stage $\left(31^{\circ} \mathrm{C}\right.$ for $\left.30 \mathrm{~min}\right)$ or at late blastula (LB), middle gastrula (MG) and 3-somite (3s) stages $\left(35^{\circ} \mathrm{C}\right.$ for $\left.30 \mathrm{~min}\right)$. From each treatment, about 200 embryos at 1,2, 3 or 5 hours after heat-shock were collected for total RNA extraction using Trizol reagent (Invitrogen Co., USA). The mRNA was reverse-transcribed using PrimeScript ${ }^{\text {Tw }}$ II 1st Strand cDNA Synthesis Kit (Takara Co., Japan), and RT-qPCR was carried out on a Rotor-Gene 6000 (Corbett Robotics Co., USA) using SYBR Green (Promega Co., USA) with primers BfHsp70-RT-F1: 5'-AGCAAGTCGCTAGGAACCCCAA-3' and BfHsp70-RT-R1: 5' - CCTCCGCCGTCTCCTTCATCT-3'. The expression level of Gapd $h$ was adopted as an internal control with primers Gapdh-RT-F1: $5^{\prime}$-GGTGGAAAGGTCCTGCTCTC-3' and Gapdh-RT-R1: 5'-CTGGATGAAAGGGTCGTTAATGG-3' (Liu et al., 2015). Three replications were performed for each sample. The reaction tubes were denatured at $95^{\circ} \mathrm{C}$ for $2 \mathrm{~min}$ followed by 40 cycles of $15 \mathrm{~s}$ at $95^{\circ} \mathrm{C}, 15 \mathrm{~s}$ at $60^{\circ} \mathrm{C}$, and $15 \mathrm{~s}$ at $72^{\circ} \mathrm{C}$. The data were quantified using the comparative $\mathrm{Ct}$ method to calculate the fold increase (Livak and Schmittgen, 2001).

\section{In situ hybridization}

Hsp70 coding sequence was amplified from cDNA templates with primer BfHsp70-F1: 5'-TCATCACCGTCCCGGCCTACT-3' and BfHsp70-R1: $5^{\prime}$-GCGTCCTGCTCTTTGTGCTTC-3', and then subcloned into a pGEM-T easy vector. The resulting plasmid was then used to synthesize a digoxigenin-labeled antisense RNA probe using Sp6 RNA polymerase (Promega Co., USA). To examine the expression patterns of exogenous Hsp70 promoter-driven genes, we also subcloned a segment of the coding sequence of $V g 1$ into the pGEM-T easy vector for RNA probe synthesis. Whole mount in situ hybridization was performed following the description by Yu and Holland (Yu and Holland, 2009).

\section{Construct preparation and microinjection}

A 791 bp promoter region of $H s p 70$ gene was amplified from the reporter construct $\mathrm{P} 1$ using primer pairs BbHsp70-promoter-F1:5'-AAGCTTCAATGGCTAACACGACATCAC-3' and BbHsp70-promoter-R1: 5'-CGGCCGCCAATCGCTCTACGTTCTCACT-3' (Li et al., 2012). The amplicon was digested with restriction enzymes Hind III and Not I (NEB, Co., USA) and then ligated into a lac $Z$ reporter vector derived from plasmid $\beta$-actin::LacZ (Feng et al., 2014) to generate Hsp70::LacZconstruct. Meanwhile, the segment was also cloned to pmCherry-1 vector (Clontech Co., Japan) at Xhol and $E c o R I$ restriction sites using a similar strategy. To induce expression of a target gene, the Hsp70::mCherry construct was further used to make Hsp $70:: C e r$ and $H s p 70:: V g 1$ by replacing the mCherry sequence with the coding sequences of Cer or Vg1 genes from B. floridae. 
The injection cocktail containing 20\% glycerol (Sangon Co., China), 2 $\mathrm{mg} / \mathrm{ml}$ Texas red dextran (Invitrogen Co., USA) and 200-300 ng/ul recombined plasmid DNA was microinjected into unfertilized eggs according to our previous report (Liu et al., 2013). After injection, the eggs were fertilized immediately and then cultured in an incubator at $25^{\circ} \mathrm{C}$ with $95 \%$ humidity. Fluorescent signals were observed under a stereoscope (SZX10, Olympus Co., Japan) and photographed under a high sensitivity confocal microscope (LSM 780-1, Zeiss Co., Germany).

\section{Detection of $\beta$-galactosidase activity}

The detection of $\beta$-galactosidase ( $\beta$-gal) activity was after the previous description (Yu et al., 2004) with a slight modification. In brief, embryos injected with Hsp70::LacZ plasmid were fixed in 1\% glutaraldehyde for 30 min at room temperature, and then washed with PBST $(0.1 \%$ Tween-20 in $1 \times$ PBS, pH 7.4) four times (10 min each). After that, the samples were stained with freshly prepared staining solution ( $4 \mathrm{mM} \mathrm{K}_{4} \mathrm{Fe}(\mathrm{CN})_{6}, 4 \mathrm{mM}$ $\mathrm{K}_{3} \mathrm{Fe}(\mathrm{CN})_{6}, 40 \mathrm{mg} / \mathrm{ml} \mathrm{X}$-gal and $0.1 \%$ Tween- 20 in $\left.1 \times \mathrm{PBS}\right)$ at $37^{\circ} \mathrm{C}$ in the dark for 2 hours or longer, and subsequently were washed at least three times (10 min each) with $1 \times$ PBST ( $\mathrm{pH} \mathrm{7.4)} \mathrm{and} \mathrm{post-fixed} \mathrm{in} 4 \%$ paraformaldehyde in $1 \times$ PBST for 1 hour at room temperature. After removing the paraformaldehyde, the embryos were quickly rinsed in $1 \times$ PBST and then mounted on slides in $80 \%$ glycerol. Finally, observation and photography were performed under an inverted microscope (IX71, Olympus Co., Japan).

\section{Acknowledgements}

This work was supported by grants from National Natural Science Foundation of China (No. 31471986, No. 31372188 and No. 31672246) and from the Fundamental Research Funds for the Central Universities of China (No. 20720160056).

\section{Author Contributions}

C.X., G.L. and Y.W. designed research; C.X., G.L., X.L. and X.D. performed experiments; C.X., G.L. and Y.W. analyzed data; and C.X., G.L. and Y.W. wrote the paper.

\section{References}

ACEMEL, R.D., TENA, J.J., IRASTORZA-AZCARATE, I., MARLETAZ, F., GOMEZMARIN, C., DE LACALLE-MUSTIENES, E., BERTRAND, S., DIAZ, S.G., ALDEA, D., AURY, J.M. et al., (2016). A single three-dimensional chromatin compartment in amphioxus indicates a stepwise evolution of vertebrate Hox bimodal regulation. Nat Genet 48: 336-341.

AJOGHLI, B., AGHAALLAEI, N., HEIMBUCHER, T. and CZERNY, T. (2004). An artificial promoter construct for heat-inducible misexpression during fish embryogenesis. Dev Biol 271: 416-430.

BENITO-GUTIERREZ, E., WEBER, H., BRYANT, D.V. and ARENDT, D. (2013). Methods for generating year-round access to amphioxus in the laboratory. PloS One 8: e71599.

BERTRAND, S. and ESCRIVA, H. (2011). Evolutionary crossroads in developmental biology: amphioxus. Development 138: 4819-4830.

BIENZ, M. (1984a). Developmental control of the heat shock response in Xenopus. Proc Natl Acad Sci USA 81: 3138-3142.

BIENZ, M. (1984b). Xenopus Hsp70 genes are constitutively expressed in injected oocytes. EMBO J 3: 2477-2483.

BOURLAT, S.J., JULIUSDOTTIR, T., LOWE, C.J., FREEMAN, R., ARONOWICZ, J., KIRSCHNER, M., LANDER, E.S., THORNDYKE, M., NAKANO, H., KOHN, A.B. et al., (2006). Deuterostome phylogeny reveals monophyletic chordates and the new phylum Xenoturbellida. Nature 444: 85-88.

DELSUC, F., BRINKMANN, H., CHOURROUT, D. and PHILIPPE, H. (2006). Tunicates and not cephalochordates are the closest living relatives of vertebrates. Nature 439: 965-968.

FENG, J., LI, G., LIU, X., WANG, J. and WANG, Y.Q. (2014). Functional analysis of the promoter region of amphioxus $\beta$-actin gene: a useful tool for driving gene expression in vivo. Mol Biol Rep 41: 6817-6826.

GARCIA-FERNANDEZ, J. and BENITO-GUTIERREZ, E. (2009). It's a long way from amphioxus: descendants of the earliest chordate. Bioessays 31(6): 665-675.

GIUDICE, G. (1989). Heat shock proteins in sea urchin embryos. Dev Growth Differ 31: 103-106.

HALLORAN, M.C., SATO-MAEDA, M., WARREN, J.T., SU, F., LELE, Z., KRONE, P.H., KUWADA, J.Y. and SHOJI, W. (2000). Laser-induced gene expression in specific cells of transgenic zebrafish. Development 127: 1953-1960.

HEIKKILA, J.J., KLOC, M., BURY, J., SCHULTZ, G.A. and BROWDER, L.W. (1985). Acquisition of the heat-shock response and thermotolerance during early development of Xenopus laevis. Dev Biol 107: 483-489.

HOLLAND, L.Z., LAUDET, V. and SCHUBERT, M. (2004). The chordate amphioxus: an emerging model organism for developmental biology. Cell Mol Life Sci 61: 2290-2308.

HUANG, S., CHEN, Z., YAN, X., YU, T., HUANG, G., YAN, Q., PONTAROTTI, P.A., ZHAO, H., LI, J., YANG, P. et al., (2014). Decelerated genome evolution in modern vertebrates revealed by analysis of multiple lancelet genomes. Nat Commun 5:5896.

HUNT, C. and CALDERWOOD, S. (1990). Characterization and sequence of a mouse Hsp70 gene and its expression in mouse cell lines. Gene 87: 199-204.

KOOP, D. and HOLLAND, L.Z. (2008). The basal chordate amphioxus as a simple model for elucidating developmental mechanisms in vertebrates. Birth Defects Res C 84: 175-187.

LANG, L., MISKOVIC, D., LO, M. and HEIKKILA, J.J. (2000). Stress-induced, tissuespecific enrichment of Hsp70 mRNA accumulation in Xenopus laevis embryos. Cell Stress Chaperon 5: 36-44

LELE, Z., ENGEL, S. and KRONE, P.H. (1997). Hsp47 and Hsp70 gene expression is differentially regulated in a stress- and tissue-specific manner in zebrafish embryos. Dev Genet 21: 123-33.

LI, D., LI, G., WANG, K., LIU, X., LI, W., CHEN, X. and WANG, Y.Q. (2012). Isolation and functional analysis of the promoter of the amphioxus Hsp70a gene. Gene 510: 39-46.

LI, G., YANG, X., SHU, Z., CHEN, X. and WANG, Y.Q. (2012). Consecutive spawnings of Chinese amphioxus, Branchiostoma belcheri, in captivity. PloS One 7: e50838.

LI, G., SHU, Z. and WANG, Y.Q. (2013). Year-round reproduction and induced spawning of Chinese amphioxus, Branchiostoma belcheri, in laboratory. PloS One8: e75461.

LI, G., FENG, J., LEI, Y., WANG, J., WANG, H., SHANG, L.K., LIU, D.T., ZHAO, H., ZHU, Y. and WANG, Y.Q. (2014). Mutagenesis at specific genomic loci of amphioxus Branchiostoma belcheri using TALEN method. J Genet Genomics 41: 215-219.

LI, G., WANG, J., YUAN, L., WANG, H. and WANG, Y.Q. (2015). A simple method for selecting spawning-ready individuals out from laboratorial cultured amphioxus population. J Exp Zool Part B 324: 629-635.

LI, G., LIU, X., XING, C., ZHANG, H., SHIMELD, S.M. and WANG, Y.Q. (2017). Cerberus-Nodal-Lefty-Pitx signaling cascade controls left-right asymmetry in amphioxus. Proc. Natl Acad Sci USA 114: 3684-3689.

LIU, X., LI, G., FENG, J., YANG, X. and WANG, Y.Q. (2013). An efficient microinjection method for unfertilized eggs of Asian amphioxus Branchiostoma belcheri. Dev Genes Evol 223: 269-278.

LIU, X., LI, G., LIU, X. and WANG, Y.Q. (2015). The role of the Pax1/9 gene in the early development of amphioxus pharyngeal gill slits. J Exp Zool Part B324:30-40.

LIVAK, K.J. and SCHMITTGEN, T.D. (2001). Analysis of relative gene expression data using real-time quantitative PCR and the $2^{-\Delta \Delta C T}$ method. Methods 25: 402-408.

MICHIUE, T. and ASASHIMA, M. (2005). Temporal and spatial manipulation of gene expression in Xenopus embryos by injection of heat shock promoter-containing plasmids. Dev Dynam 232: 369-376.

MOLINA, A., BIEMAR, F., M LLER, F., IYENGAR, A., PRUNET, P., MACLEAN, N., MARTIAL, J.A. and MULLER, M. (2000). Cloning and expression analysis of an inducible HSP70 gene from tilapia fish. FEBS Lett 474: 5-10.

ODA, S., MIKAMI, S., URUSHIHARA, Y., MURATA, Y., KAMEI, Y., DEGUCHI, T., KITANO, T., FUJIMORI, K.E., YUBA, S. and TODO, T. (2010). Identification of a functional medaka heat shock promoter and characterization of its ability to induce exogenous gene expression in medaka in vitro and in vivo. Zool Sci 27: 410-415

ONAI, T., YU, J.K., BLITZ, I.L., CHO, K.W.Y. and HOLLAND, L.Z. (2010). Opposing Nodal $/ \mathrm{Vg} 1$ and BMP signals mediate axial patterning in embryos of the basal chordate amphioxus. Dev Biol 344: 377-389.

PELHAM, H.R. and BIENZ, M. (1982). A synthetic heat-shock promoter element confers heat-inducibility on the herpes simplex virus thymidine kinase gene. EMBO J 1: 1473-1477. 
PUTNAM, N.H., BUTTS, T., FERRIER, D.E.K., FURLONG, R.F., HELLSTEN, U., KAWASHIMA, T., ROBINSON-RECHAVI, M., SHOGUCHI, E., TERRY, A., YU, J.K. et al., (2008). The amphioxus genome and the evolution of the chordate karyotype. Nature 453: 1064-1071.

SANTACRUZ, H., VRIZ, S. and ANGELIER, N. (1997). Molecular characterization of a heat shock cognate cDNA of zebrafish, hsc70, and developmental expression of the corresponding transcripts. Dev Genet 21: 223-233.

SAUERT, K., KAHNERT, S., ROOSE, M., GULL, M., BRANDLI, A.W., RYFFEL, G.U. and WALDNER, C. (2012). Heat-shock mediated overexpression of HNF1b mutations has differential effects on gene expression in the Xenopus pronephric kidney. PloS One 7: e33522.

SOUKUP, V., YONG, L.W., LU, T.M., HUANG, S.W., KOZMIK, Z. and YU, J.K. (2015). The Nodal signaling pathway controls left-right asymmetric development in amphioxus. Evol Dev 6: 1-23.

STRINGHAM, E.G. and CANDIDO, E.P. (1993). Targeted single-cell induction of gene products in Caenorhabditis elegans: a new tool for developmental studies. $J$ Exp Zool 266: 227-233.

WANG, H., LI, G. and WANG, Y.Q. (2015). Generating amphioxus Hedgehog knockout mutants and phenotype analysis. Hereditas 37: 1036-1043 (in Chinese with English abstract)
WANG, Y.Q., ZHANG, Q.J., LÜ, X.M., ZHONG, J. and SUN, Y. (2006). Laboratory culturing and acquirement of the second filial generation of amphioxus. Zool. Res. 27: 631-634 (in Chinese with English abstract).

WANG, Z. and LINDQUIST, S. (1998). Developmentally regulated nuclear transport of transcription factors in Drosophila embryos enable the heat shock response. Development 125: 4841-4850.

WYSOCKA, A. and KRAWCZYK, Z. (2000). Green fluorescent protein as a marke for monitoring activity of stress-inducible $\mathrm{Hsp} 70$ rat gene promoter. $\mathrm{Mol}$ Cell Biochem 215: 153-156.

YANG, K.Y., CHEN, Y., ZHANG, Z., NG, P.K-S., ZHOU, W.J., ZHANG, Y., LIU, M., CHEN, J., MAO, B. and TSUI, S.K-W. (2016). Transcriptome analysis of different developmental stages of amphioxus reveals dynamic changes of distinct classes of genes during development. Sci. Reports 6: 23195.

YU, J.K., HOLLAND, N.D. and HOLLAND, L.Z. (2004). Tissue-specific expression of FoxD reporter constructs in amphioxus embryos. Dev Biol 274: 452-461.

YU, J.K. and HOLLAND, L.Z. (2009). Amphioxus whole-mount in situ hybridization. Cold Spring Harb Protoc: pdb.prot5286.

ZHANG, Q.J., SUN, Y., ZHONG, J., LI, G., LÜ, X.M. and WANG, Y.Q. (2007). Continuous culture of two lancelets and production of the second filial generations in the laboratory. J Exp Zool Part B 308: 464-472. 


\section{Further Related Reading, published previously in the Int. J. Dev. Biol.}

From the American to the European amphioxus: towards experimental Evo-Devo at the origin of chordates Jordi Garcia-Fernàndez, Senda Jiménez-Delgado, Juan Pascual-Anaya, Ignacio Maeso, Manuel Irimia, Carolina Minguillón, Èlia BenitoGutiérrez, Josep Gardenyes, Stéphanie Bertrand and Salvatore D'Aniello Int. J. Dev. Biol. (2009) 53: 1359-1366 https://doi.org/10.1387/ijdb.072436jg

Evolution of CUT class homeobox genes: insights from the genome of the amphioxus, Branchiostoma floridae Naohito Takatori and Hidetoshi Saiga Int. J. Dev. Biol. (2008) 52: 969-977 https://doi.org/10.1387/ijdb.072541nt

Peter Holland, homeobox genes and the developmental basis of animal diversity Sebastian M. Shimeld Int. J. Dev. Biol. (2008) 52: 3-7 https://doi.org/10.1387/ijdb.072394ss

Developmental expression of the High Mobility Group B gene in the amphioxus, Branchiostoma belcheri tsingtauense

Xiangwei Huang, Lifeng Wang and Hongwei Zhang

Int. J. Dev. Biol. (2005) 49: 49-46

http://www.intjdevbiol.com/web/paper/041915xh

Cell morphology in amphioxus nerve cord may reflect the time course of cell differentiation T C Lacalli

Int. J. Dev. Biol. (2000) 44: 903-906

http://www.intjdevbiol.com/web/paper/11206331

Embryonic development of heads, skeletons and amphioxus: Edwin S. Goodrich revisited P W Holland

Int. J. Dev. Biol. (2000) 44: 29-34

http://www.intjdevbiol.com/web/paper/10761843

Amphioxus Hox genes: insights into evolution and development

$\mathrm{J}$ Garcia-Fernàndez and $\mathrm{P}$ W Holland

Int. J. Dev. Biol. (1996) 40: S71-S72

http://www.intjdevbiol.com/web/paper/9087701

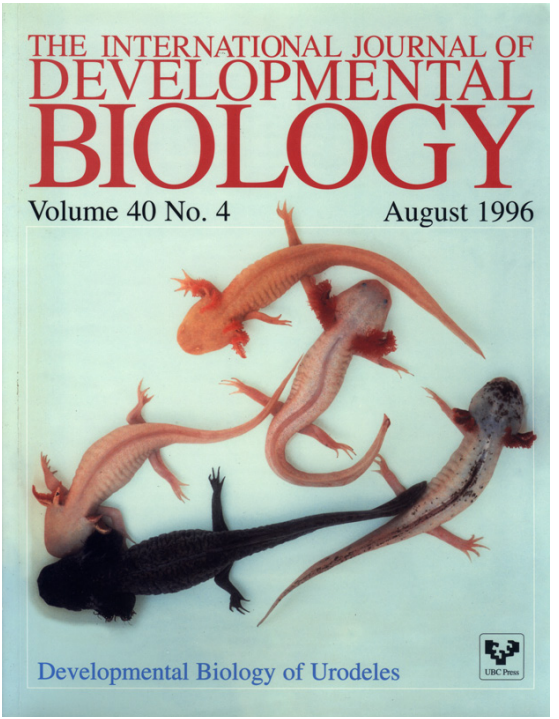

5 yr ISI Impact Factor $(2013)=2.879$
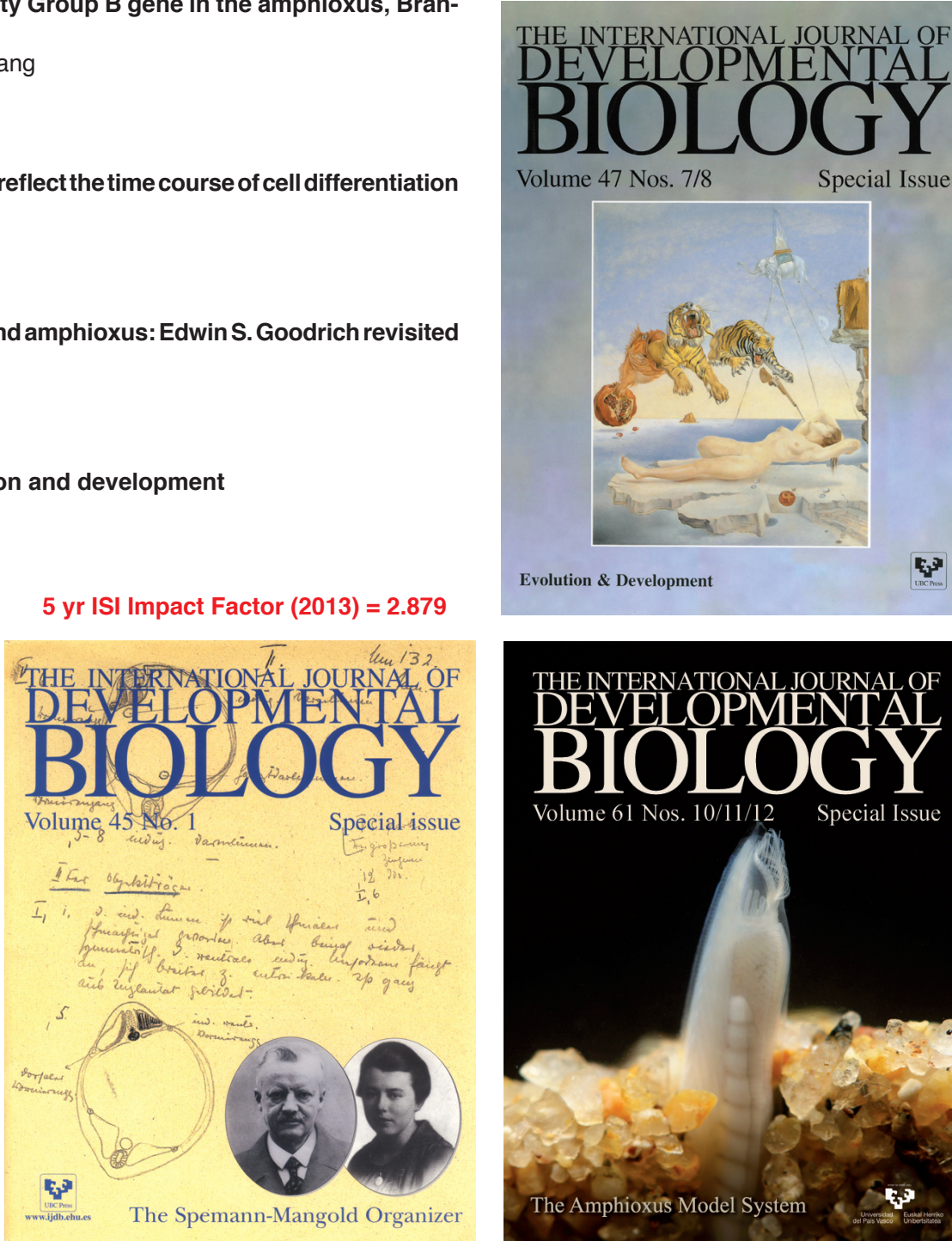

Volume 47 Nos. $7 / 8$ Special Issue

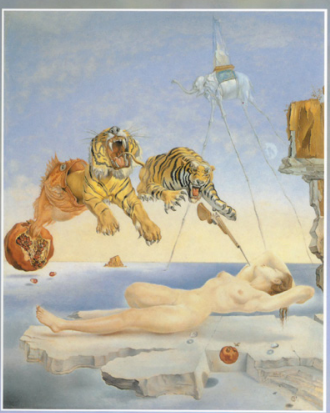

Evolution \& Development

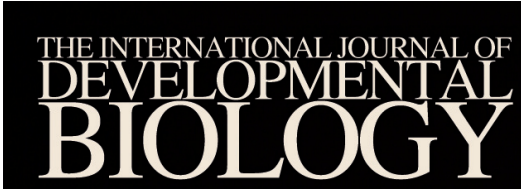

Volume 61 Nos. 10/11/12 Special Issue

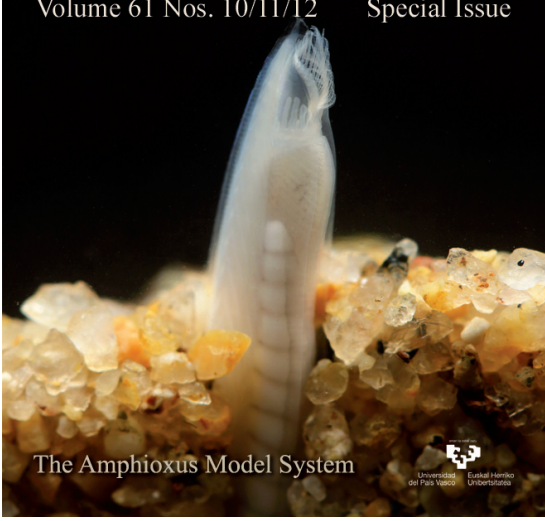

